\title{
Hydrogel-Based Non-Autologous Cell and Tissue Therapy
}

BioTechniques 29:564-581 (September 2000)

\author{
U. Zimmermann, S. Mimietz, \\ H. Zimmermann ${ }^{1}$, M. Hill- \\ gärtner, H. Schneider, J. Lud- \\ wig, C. Hasse ${ }^{2}$, A. Haase, M. \\ Rothmund $^{2}$ and G. Fuhr ${ }^{1}$ \\ Universität Würzburg, \\ Würzburg, ${ }^{1}$ Humboldt-Univer- \\ sität zu Berlin, Berlin, ${ }^{2}$ Philipps- \\ Universität Marburg, Marburg, \\ Germany
}

\section{ABSTRACT}

Many diseases are closely tied to deficient or subnormal metabolic and secretory cell functions. Milder forms of these diseases can be managed by a variety of treatments. However, it is often extremely difficult or even impossible to imitate the moment-to-moment fine regulation and the complex roles of the hormone, factor or enzyme that is not sufficiently produced by the body. Immunoisolated transplantation is one of the most promising approaches to overcome the limitations of current treatments. Non-autologous (transformed) cell lines and allogeneic and xenogeneic cells/tissues that release the therapeutic substances are enclosed in immunoprotective microcapsules. The microcapsules avoid a lifetime of immunosuppressive therapy while excluding an immune response in the host. Research in this direction has shown the feasibility of microcapsules based on hydrogels (particularly of alginate) for transplantation of non-autologous cells and tissue fragments. Numerous technical accomplishments of the immunoisolation method have recently made possible the first successful long-term clinical applications. However, realizing the potential of immunoisolated therapy requires the use of several factors that have received limited attention in the past but are important for the formulation of hydrogel-based im munoisolation systems that are highly versatile, potentially economical and can gain medical approval.

\section{INTRODUCTION}

The past ten years have seen tremendous advances in the transplantation of allogeneic tissue and organs. However, patients must receive a lifetime of im munosuppressive therapy to avoid graft rejection. Encapsulated cell therapy (i.e., immunoisolated transplantation of non-autologous cells, tissues or even organs) is an alternative, revolutionary approach to replace lost body function of immuno-incompatible recipients without the need for long-term treatment with immunosuppressives. It is obvious that transplantation of immunoisolated, allogeneic (intraspecific, human), xenogeneic (interspecific, nonhuman) or transformed cells has an enormous potential because of the nearly unlimited source of genetically engineered donor cells that produce the therapeutic factor. In theory, the endpoint of immunoisolated "organ reconstruction" is a capsule system that establishes a long-term immunological barrier between the transplant and its host while still allowing the unrestricted diffusion of nutrients, oxygen, metabolites, messengers and hormones to maintain the function of the transplant in a sequestered environment.

However, evaluation of the concept of encapsulated cell therapy by performance of numerous in vitro experiments and animal studies has shown that the structural, chemical, immunological and mechanical characteristics of the "biohybrid organ" must be carefully tuned to prevent functional loss and capsule breakage that result in early graft failure and immune rejection.

The demands placed on an immunoisolated capsule vary with the type of therapeutic application. Encapsulation of endocrine tissue has attracted the attention of many scientists in the field because transplants involve only small tissue pieces (or a relatively small volume of cells) and secrete easily identifiable factors (e.g., hormones). Salient exam ples are the encapsulation of pancreatic islets, parathyroid tissue, dopamine-secreting and other appropriate transformed cell lines for the treatment of diabetes mellitus, hypoparathyroidism, Parkinson's, Alzheimer's and other neurodegenerative diseases, respectively.

Macroencapsulated and microencapsulated endocrine tissue systems have been explored in animal studies. These terms differentiate the physical arrangement by which the donor cells are isolated from the host immune system. Macroencapsulation systems include diverse planar and tubular configurations (e.g., hollow fibers, selective permeability tubular membranes, diffusion chambers, etc.). Promising animal studies and the first short-term clinical trials with allogeneic islets encapsulated in hollow fibers are reported in the literature (46). However, these and other studies (44, 46) have also demonstrated severe limitations of macrocapsules (e.g., limited diffusion surface area, foreign body reactions, breakage of the membrane, transplant geometry and size, etc.).

In contrast to the macrocapsule systems, substantial progress has been reported on the development of microencapsulated cells/tissues, that is, on the encapsulation and subsequent transplantation of individual islets, parathyroid tissue pieces or other cells/tissues in small beads. Various polymers have been used for immunoisolation $(28,38)$. Hydrogel-based and particularly alginate-based microencapsulation is currently a favored approach because the use of hydrogel capsules in animal studies and recent clinical trials suggests that the requirements for long-term im munoisolation and simultaneous maintenance of transplant function can most probably be satisfied by this system.

Rather than present a thorough review of the vast literature on this sub- 
ject matter (44), this article highlights important factors when developing hydrogel-based cell therapy. Emphasis is placed on understanding the biological, chemical and physical properties that determine the success of hydrogelbased transplants and on the challenging problems that still exist and have prevented long-term treatment of endocrine diseases by encapsulated cell therapy. Suggestions are presented for designing microcapsules that may obtain regulatory approval for routine clinical applications in the near future.

\section{Fabrication of Microcapsules}

Gel formation can be achieved by ionic cross-linking of a charged polymer, by cooling off a heated polymer and by chemical reactions. Alginate is an example of the first group, agarose of the second and gelatin (cross-linked with glutaric dialdehyde) of the third (7). Among the hydrogels used for microencapsulation of individual cells/tissues, alginate has been and will continue to be one of the most important biomaterials. Therefore, in view of the vast literature, we focus in this review on alginate-based encapsulation to highlight the principles of immunoisolated microencapsulation.

Alginates are natural polymers isolated from kelp. They consist of unbranched, anionic polysaccharides that are composed of homopolymeric regions of 1,4-linked $\alpha$-L-guluronic acid (G-blocks) and $\beta$-D-mannuronic acid (M-blocks) interspaced with regions of mixed sequence (MG-blocks). Alginates have gel-forming properties when multivalent inorganic cations (e.g., $\mathrm{Ca}^{2+}$, $\mathrm{Ba}^{2+}$ and $\mathrm{Fe}^{3+}$ ) bind preferentially to the carboxyl groups of the G-blocks (69).

Most current transplantation work is done with $\mathrm{Ca}^{2+}$ and $\mathrm{Ba}^{2+}(21,44,47)$. Solid $\mathrm{Ba}^{2+}$ alginate capsules are mechanically stable and are the more appropriate choice for long-term transplantation (27,60). A drawback of solid $\mathrm{Ca}^{2+}$ alginate beads is their ready solubilization in the presence of phosphate, citrate and other chelating agents. This feature may be advantageous when, for example, autologous chondrocytes and osteoblasts are transplanted for the restoration of cartilage and bone $(39,60)$. For long-term transplantation of allogeneic or xenogeneic cells/tissues, a "bi-polymer" approach is com monly used to circumvent the stability problems of $\mathrm{Ca}^{2+}$ alginate capsules. In bi-polymer encapsulation, $\mathrm{Ca}^{2+}$ alginate capsules react with a large polycation (usually poly-L-lysine; molecular mass around $20 \mathrm{kDa}$ ), producing a surface film, and the gel is subsequently liquefied by removal of $\mathrm{Ca}^{2+}(21)$. Even though these liquid core capsules are popular, they have several disadvantages compared with $\mathrm{Ba}^{2+}$ alginate capsules $(17,18,26,76,89)$. The fabrication process is impractical and difficult to control. The beads also exhibit an insufficient stability because of the high internal colloid-osmotic pressure. Furthermore, free poly-L-lysine that may be liberated upon capsule breakage shows strong cytotoxicity. Therefore, this compound is used as an antineoplastic agent (3).

$\mathrm{Ba}^{2+}$ alginate capsules do not exhibit these drawbacks, but the free $\mathrm{Ba}^{2+}$ ions must be quickly removed after gelation because this divalent cation is a strong inhibitor of $\mathrm{K}^{+}$channels in biomembranes at concentrations greater than $5-10 \mathrm{mM}$. It is because of this toxicity that most investigators used $\mathrm{Ca}^{2+}$ as the cross-linking agent in the past. However, toxicity effects can be completely avoided if excess $\mathrm{Ba}^{2+}$ ions after gelation are eliminated by precipitation with sulfate (35). Organic buffer molecules used frequently in the formation of $\mathrm{Ba}^{2+}$ alginate beads (17, $20,85)$ are also cytotoxic when released from the capsule during transplantation and must be replaced by biomolecules such as histidine $(35,39)$.

For capsule preparation, many dropping devices are described in the literature, a few of which are commercially available. They can be divided into two classes: drop formation/extrusion and jet breakage (21). The first class com prises drop formation under gravity, coaxial air or liquid flow or electrostatic potential; the second class includes vibrating and rotating capillary jet breakage. The underlying principle is that a liquid, when forced through a nozzle, is extruded initially as individual droplets. However, with an increasing flow rate, the liquid forms a laminar jet that breaks into small droplets either naturally or with the aid of vibrating or rotating systems. Based on laminar jet break-up, a multinozzle apparatus has been developed to produce small beads (200-300 $\mu \mathrm{m}$ in diameter) with narrow size distributions and in large quantities under sterile and reproducible conditions (6). Despite these extremely beneficial features, two- or three-channel air-jet bead generators are more appropriate for encapsulated cell therapy because-in contrast to all other generators-high-viscosity alginates can be used that are advantageous for longterm transplant functions (39). Threechannel air-jet generators allow the formation of homogeneous and spatially heterogeneous beads, for example, those containing a liquid or solid (cellcontaining) core of low alginate concentration surrounded by a layer of high alginate concentration. Such capsules have excellent properties of mass transfer and immunoprotection and are also very stable.

\section{Requirements for Producing Transplantation-Grade Alginates}

Biocompatibility requires consideration of the encapsulation material, process and other factors that may interfere with the immune system of the host. Many published reports have used commercial alginate as a matrix for transplantation of allogeneic and xenogeneic cells/tissues (44). When empty capsules made of commercial alginates were implanted into the peritoneal cavity or under the kidney capsule of rodents and other animals, heavy foreign body reactions associated with pericapsular fibrosis were observed within a few weeks (Figure 1A). Several authors have traced back the inflammatory response and fibrotic overgrowth of the empty capsules to the M- and MGblocks of the alginates and recommended the use of high-G alginates for microencapsulation $(45,56)$. In light of recent results obtained with purified high-M or high-G alginates $(13,17,18$, $20,90)$, it seems clear that the response against contaminants of the alginate was mistakenly interpreted as a response against the M-residues in the alginate. Separation of commercial alginate by free-flow electrophoresis has shown (90) that this material contains 10-20 mitogenic impurities that 


\section{Review}

ultimately engender fibrotic overgrowth of the capsules and, consequently, graft failure. Thus, alginatebased cell therapy is unlikely to be successful unless due consideration is given to the purification process of the alginates.

The method of purification depends on the starting material. Owing to the source, harvesting and extraction processes, the biomass is contaminated not only by natural mitogenic compounds but also by bacterial and animal-originating impurities. Common contaminants are proteins, carbohydrates, fatty acids, phospholipids, lipopolysaccharides, toxins and polyphenols (68). Subsequent treatment of the harvested algae with formaldehyde introduces further complications. Therefore, multi-step, costly and time-wasting procedures (including repeated extraction, concentration of large volumes, precipitation, dissolution, centrifugation, dialysis steps, etc.) must be used to remove mitogenic impurities from commercial alginates (43). Even though material purified from commercial alginate has been successfully used in animal studies and clinical trials $(19,33,89)$, the variation in the initial composition and the vast variety of contaminants make the reproducible purification of alginates very difficult. The problems can be circumvented when fresh stipes of brown algae harvested directly from the sea or preferably (because of the absence of any pollution) sporophytes of brown algae grown in bioreactors under defined conditions are used for alginate extraction (39).

Purity is not the only obligatory requirement for a medical product. Attention must also be concentrated on the possible degradation of polymeric chains and changes in the G:M ratio and in the molecular mass distribution of the alginate (due to adsorption onto a solid phase) during processing when developing a purification regime. For example, EDTA and charcoal, which are com monly used for extraction and purification of commercial alginates $(14,43)$, usually result —independent of the origin of the algae-in low-viscosity alginate that has several drawbacks for immunoisolation compared with highviscosity alginates. Cleavage of the polymer chains and lowering of the viscosity of the alginate can also occur by

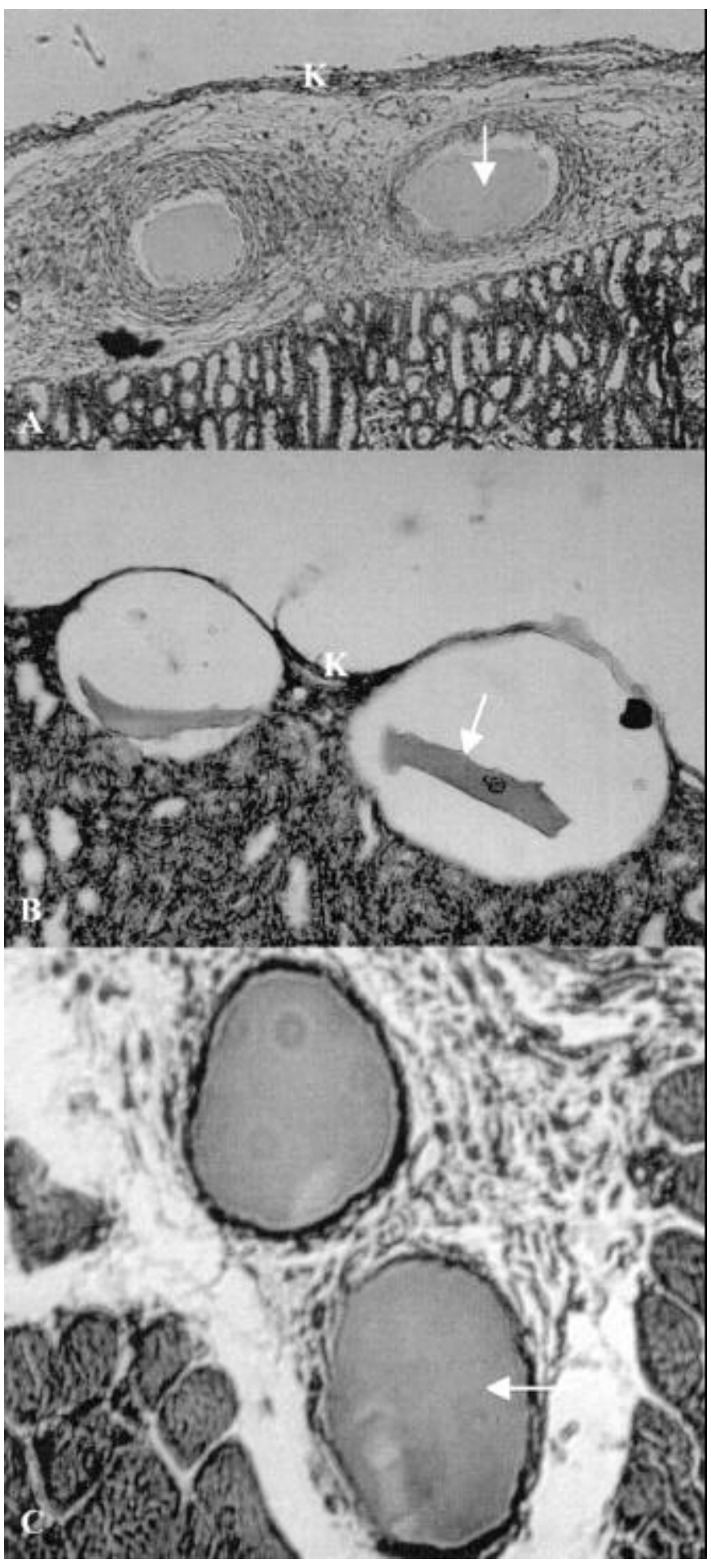

Figure 1. In vivo bioassay for the detection of mitogenic impurities in empty $\mathrm{Ba}^{2+}$ alginate capsules (diameter $300-400 \mu \mathrm{m}$ ) based on the induction of fibrotic overgrowth from the immune response of the host. (A) Capsules (arrow) made from commercial, unpurified alginate and retrieved three weeks after implantation beneath the kidney capsule $(\mathrm{K})$ of a spontaneously diabetic BB rat. (B and $\mathrm{C}$ ) Capsules (arrows) made from purified and highly viscous alginate according to the purification regime in References 35 and 39; (B) beads retrieved three weeks after implantation beneath the kidney capsule (K) of a $\mathrm{BB}$ rat and $(\mathrm{C})$ capsules (diameter about $400 \mu \mathrm{m}$ ) retrieved four weeks after implantation in the muscle of a baboon $(35,39)$. Note that because of the fixation process, the alginate beads may collapse (B) or may become deformed (C) (see text). 
filtration through syringes with very narrow tip diameters $(0.1 \mu \mathrm{m})$ usually used for sterilization of the solution (14).

While at the outset of the development of a purification process the attention will be focused mainly on purity and stability of the polymeric chain distribution, it is essential for routine clinical application that the purification regime can be scaled up in a reproducible manner and at minimum cost.

A purification regime for fresh algal material was recently published that allows the reproducible production of therapeutic quantities of biocompatible alginate at reasonable cost $(35,39)$. Simultaneously, if required, it yields high-viscosity alginates, with narrow molecular mass distribution (molecular mass larger than $300 \mathrm{kDa}$, determined by viscosity measurements) $(39,65)$.

Before regulatory approval of the purified alginate can be granted, analytical work must validate a given purification regime and assure the quality of the product for transplantation. Current routine analytical assays comprise measurements of proteins, endotoxins, phenoliclike compounds and other contaminants $(35,43)$. Although necessary, these analytical methods do not yield sufficient information about the immunological response of the alginate under transplantation conditions. A better way of addressing this issue is to use the "mixed lymphocyte" assay, which is based on the co-stimulation (and subsequent proliferation) of murine splenocytes by lipopolysaccharide and mitogenic alginate (89). The co-stimulatory effect of these compounds on the splenocytes correlates well with the occurrence of fibrosis in animal systems. However, it cannot completely replace laboratory animal studies at present because alginate samples that do not exhibit any mitogenic activity in the in vitro tests can still provoke a weak foreign body reac-

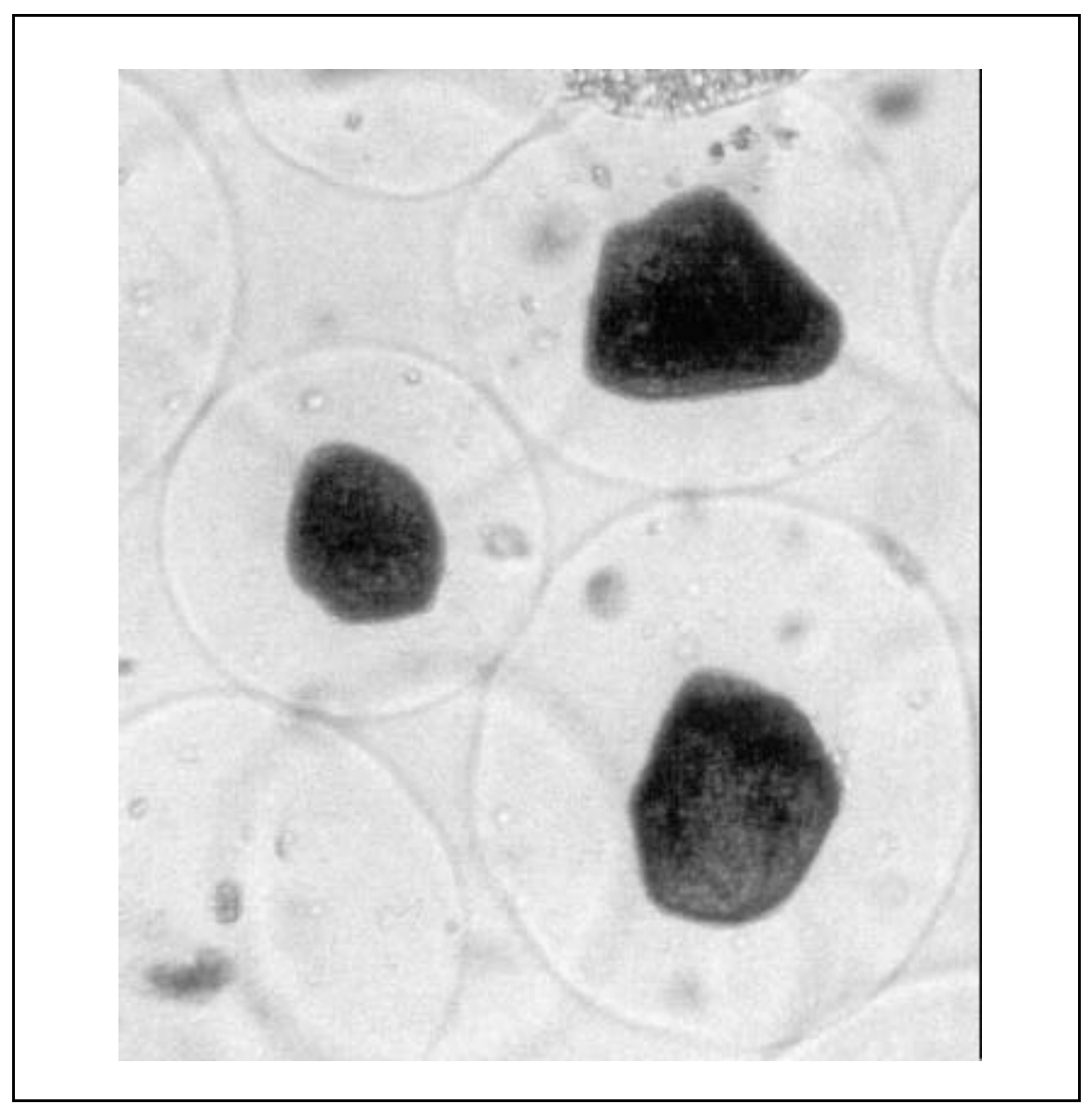

Figure 2. Uniform preparation of porcine pancreatic islets immunoisolated by $\mathrm{Ba}^{2+}$ alginate capsules of small diameter. Encapsulation was made with high-viscosity alginate purified according to Reference 35 . 
tion under implantation conditions, presumably because of the presence of trace sulfated polysaccharides (2).

Only a few groups have dealt with this subject, although developments of novel and more efficient "cell assays" are extremely important for the production of transplantation-grade alginate. These may be based (among other things) on the finding that mitogenic (low-viscosity) alginates affect cell shape, metabolism and growth $(36,74)$.

To assess the biocompatibility of alginate, spontaneously diabetic $\mathrm{BB}$ rats are the most stringent small animal models to date, presumably because of their elevated macrophage activity $(30,51)$. Results obtained in this animal model are easily transposable to the clinical situation in humans. Lewis and other rat strains as well as mice (e.g., $\mathrm{BALB} / \mathrm{C}$ ) are also frequently used as animal models $(14,81)$, but they are significantly less sensitive to mitogenic impurities in the alginate than the $\mathrm{BB}$ rats. A typical example of $\mathrm{Ba}^{2+}$ crosslinked beads made up of alginate (purified, according to Reference 35) and retrieved three weeks after implantation beneath the kidney capsule of a BB rat is shown in Figure 1B. In contrast to commercial, unpurified alginate (Figure 1A), no significant fibrotic overgrowth can be seen (65). The biocom patibility of purified alginate is also suggested by implantation studies in baboons (unpublished results). As indicated by Figure 1C, empty beads retrieved from the muscle of a baboon after four-week implantation show only a slight loose fibrotic overgrowth on some beads that should not reduce nutrient and oxygen transfer.

\section{Animal Studies and Clinical Trials}

Most transplantations of endocrine tissue have been performed with encapsulated islets and parathyroid tissue. While transplantation of parathyroid tissue in animals and humans was carried out exclusively with $\mathrm{Ba}^{2+}$ capsules made up of purified alginate, islet transplantations in animals were performed predominantly with alginate-poly-L-lysine capsules using commercial, lowviscosity alginate $(17,19,20,24)$. As outlined above, this imposes frequent difficulties in comparing the data and re- sults because of minor modifications of the capsule composition, differences in the precultivation of the cells/tissues, different donors and transplantation sites, and differences in the evaluation of the experimental data (13).

Despite these complications, numerous (mostly intraperitoneal) allo- and xenotransplantations with rat, porcine or human islets have shown $(48,55$, $76,79,82$ ) that blood glucose of diabetic mice and rats can be normalized for about 100-150 days. Occasionally, some grafts functioned up to one year. However, many reports $(44,51,83)$ indicate that graft failure could occur even two weeks after transplantation. Normalization of hyperglycemia by xenotransplantation of encapsulated islets has also been described for spontaneously diabetic dogs and cynomolgus monkeys $(70,72,80,87)$. Treatment of a patient with insulin-dependent diabetes mellitus (IDDM) with immunoprotected, intraperitoneally transplanted allogeneic islets has yielded promising results, but the information from this first human trial is limited because of the administration of cyclosporin (71).

Accordingly, allo- and xenotransplantation of rat and porcine islets en- capsulated in $\mathrm{Ba}^{2+}$ capsules (Figure 2) made of purified, high-viscosity alginate (39) demonstrated long-lasting normoglycemia in diabetic mice and rats, even though earlier failure of some grafts was also observed (about 30\%) $(86,89)$. Promising results are reported for allo- and xenotransplantation of parathyroid glands in rats $(34,89)$ by using both low- and high-viscosity alginates purified according to References 35 and 43, respectively. Throughout the six-month study period, the levels of parathormone (PTH) and calcium in the blood were always concordant. Histology of retrieved transplants revealed intact capsules and vital tissue. The transplants were partly covered by a thin fibrotic layer that apparently did not significantly affect the function of the encapsulated tissue.

Transplantation of $\mathrm{Ba}^{2+}$ alginate-encapsulated, subclinical allogeneic parathyroid tissue into the nondominant forearm muscles of two patients with hypoparathyroidism demonstrated normocalcemia and normal levels of PTH shortly after surgery (Figure 3) (33). The patients did not receive any im munosuppressives. With ongoing transplantation, they reported an impressive

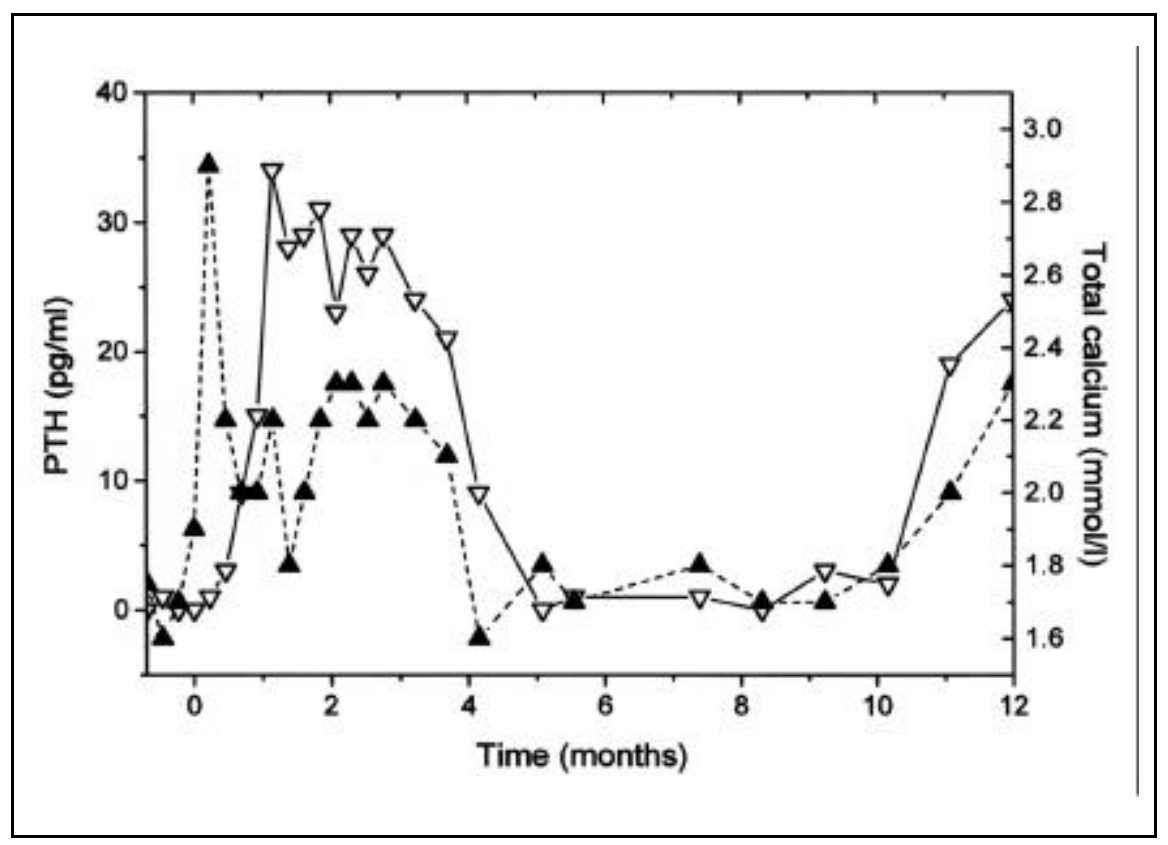

Figure 3. $\mathrm{Ca}^{2+}$ (filled triangles) and parathormone (PTH; open triangles) levels in a patient with hypoparathyroidism after allotransplantation of parathyroid tissue into the muscle of the nondominant forearm. The allogeneic tissue pieces were encapsulated by gelation of purified (low-viscosity) alginate (43) with $\mathrm{Ba}^{2+}$. Note that graft failure occurred after about three months but that functional activity of the transplant was recorded again about one year after transplantation (see text). 
improvement of symptoms of sequelae of hypoparathyroidism. After about 90 days, graft failure occurred, but on reexamination about one year later, one of the patients was nearly normocalcemic (Figure 3 ) and free of symptoms again, requiring much less calcium and vitamin $\mathrm{D}$ than before transplantation. Tests (9) revealed that the PTH was released from the transplantation arm.
However, residues of the alginate capsules or of the allogeneic tissue could not be found when the transplantation site was reexamined in the other patient after about 10 months. The reasons for this finding are unknown, but it seems possible that either the capsules had migrated from the transplantation site or-more likely due to in vivo studies (see previously mentioned litera-

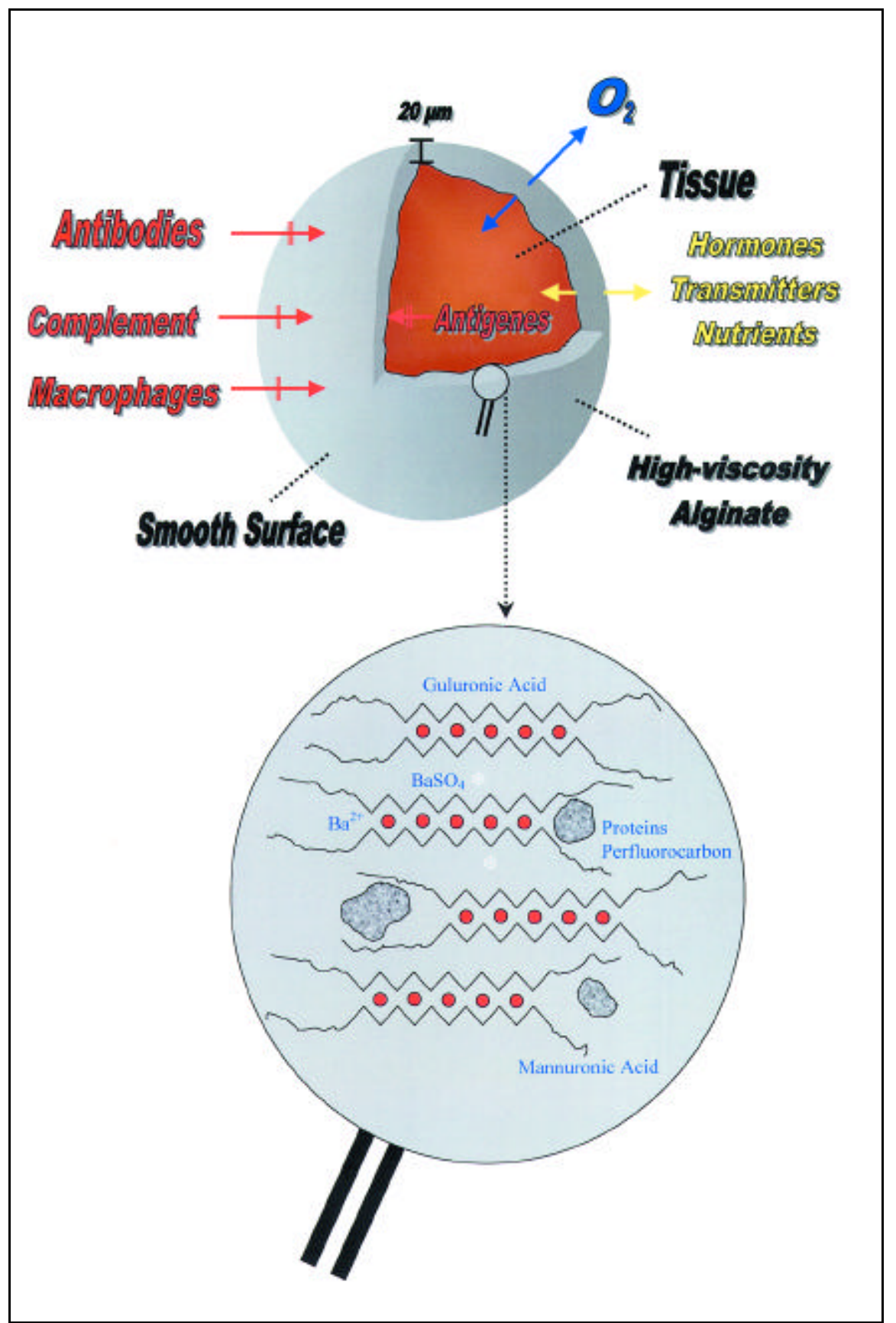

Figure 4. Concept for a $\mathrm{Ba}^{2+}$ alginate microcapsule that should fulfill the requirements for longterm functional transplantation of non-autologous cells (see text). 
ture)_that the alginate matrix had been degraded by macrophages and replaced correspondingly by a thin fibrotic layer that did not prevent nutrient or hormone exchange.

\section{Surface Compatibility and Capsule Stability}

In light of the previous results, there is no doubt that the advent of amitogenic alginate has greatly improved the biocompatibility of solid $\mathrm{Ba}^{2+}$ alginate and alginate-poly-L-lysine capsules (19, $20,33,71,90)$. However, the animal and clinical data also showed that further refinements of the physical and chemical properties of the microcapsule system are needed before a routine therapeutic application can be considered. These are summarized in Figure 4.

\section{Topography}

The cascades of fibrotic overgrowth and alginate capsule degradation have not yet been studied in depth. However, observations made with biomaterialderived or totally synthetic implants suggest that the cellular response of the host to the implant is not only determined by the chemical reactivity but also by the topography of its surface $(16,67)$. While purified alginate gels cannot serve as a substratum for cell attachment, tiny crevices and mechanical imperfections in the surface of the microcapsules present suitable targets for the attachment and subsequent spreading, migration and growth of anchorage-dependent cells (such as monocytes, macrophages, fibroblasts, etc.). Deposition of attachment factors from the surrounding tissue and blood capillaries on the bead surfaces can serve as an attachment substratum as well.

Once an individual cell has attached to a substratum and spread, it will migrate on the surface and regularly release material traces, as shown recently by atomic force microscopy (AFM) and other methods for various anchoragedependent cells on artificial surfaces $(25,88)$. According to Figure 5, these material traces can be grouped in two classes: (i) discrete, high-order dendritic structures that are well organized and enveloped by membranes and (ii) smaller, nonorganized material traces that randomly cover the migration area of the crawling cell. There is some evidence that the dendritic structures contain actin and arise from the pseudopods of the migrating cells and that the random traces contain collagen. In vitro experiments have shown (31) that collagen-coated $\mathrm{Ba}^{2+}$ alginate capsules are a perfect substratum for cell attachment and for growth to confluence. Thus, it seems likely that fibrotic overgrowth of the capsules is initiated once deposition of cellular material occurs and, in turn, the adhesiveness of the surface of the microcapsules changes.

One of the urgent needs for advancement in the area of encapsulated cell therapy is to understand the relationship between surface topography of microcapsules and induction of foreign body reactions. Attempts to evaluate the topography of the alginate bead's sur- face by electron microscopy techniques or by AFM have long been hampered by the high water content of the gels (about 98\%) and by the soft and elastic properties of the material. Recently, alginate gel surfaces have come under careful scrutiny by using advanced AFM (35). This technique can acquire three-dimensional images of surfaces within an aqueous environment at high resolution and is thus the method of choice for scanning of gel surfaces (84). Applying AFM to alginate gels requires the use of non-contact mode, low forces and very slow scanning rates (77).

To differentiate between topographical features of the surface and structures arising from the tip-sample interaction (artifacts), forward and backward scan lines have to be compared. Only when there are no significant discrepancies between the two scans can the struc-

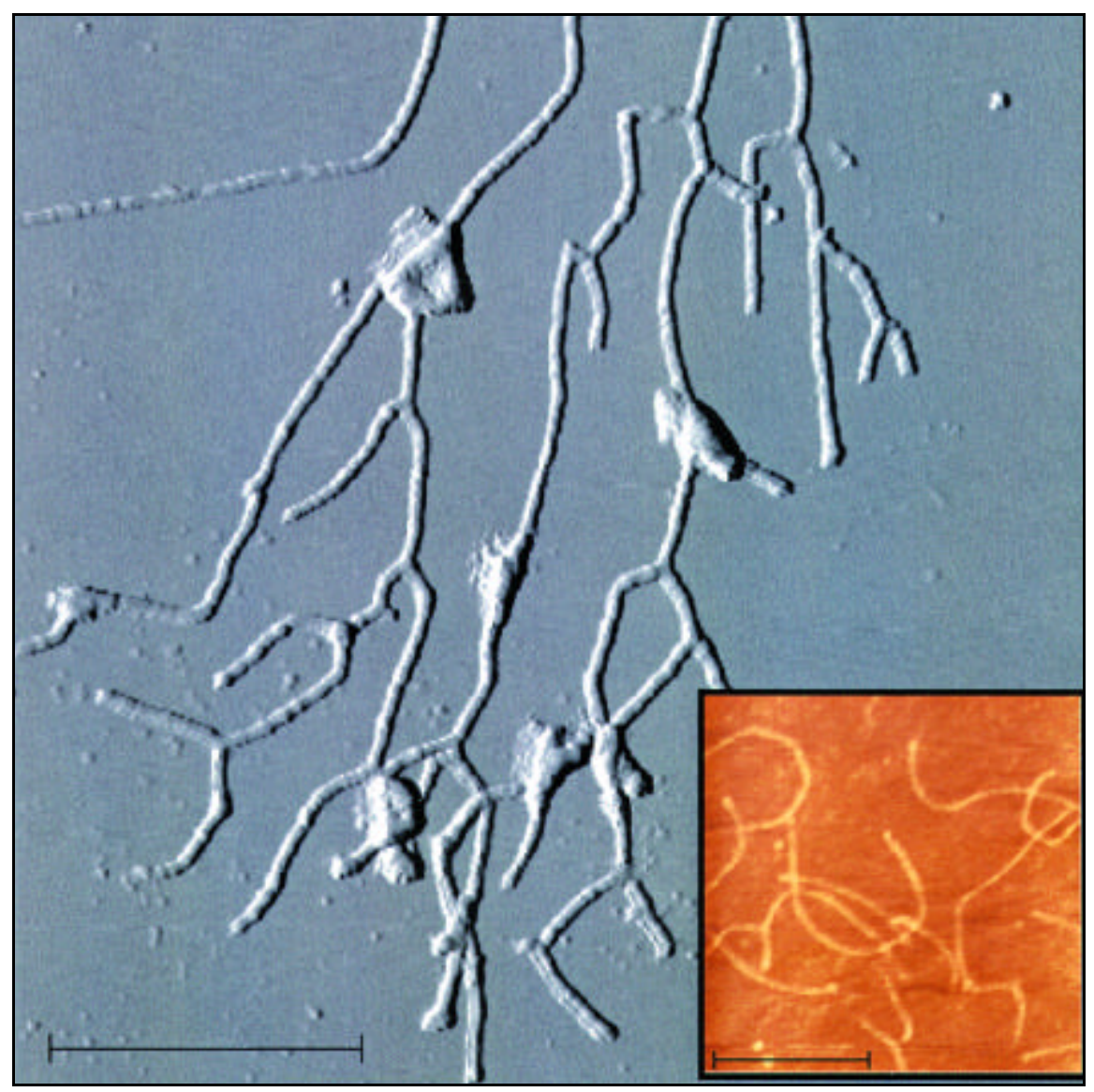

Figure 5. Cellular material released from an anchorage-dependent cell (not shown) when moving over a glass surface. The AFM measurements were performed in an aqueous environment by using noncontact mode. The image is presented in the so-called shadow mode where height information is lost but small corrugations are emphasized. There are two classes of material traces: relatively large dendritic, organized structures and background depositions (inset) that are randomly oriented beneath the migration area of the migrating cell. Bars $=10 \mu \mathrm{m}$ and $2 \mu \mathrm{m}$ (inset) 

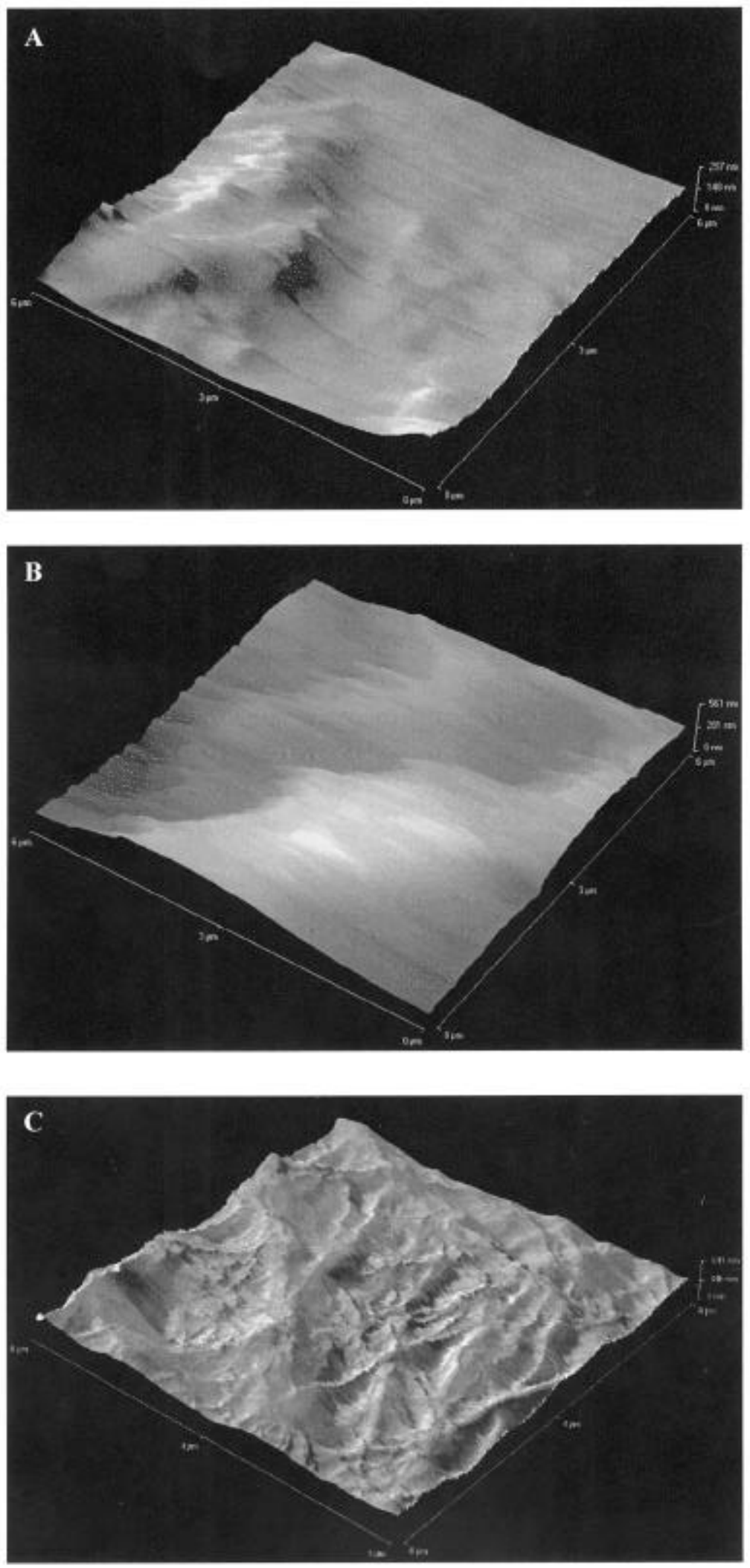

tures be recognized as real. AFM im ages of empty solid $\mathrm{Ba}^{2+}$ capsules made up of purified alginate and produced by an air-jet droplet generator are given in Figure 6. A comparison of beads incubated for four weeks in saline solution (Figure 6A) with beads retrieved after a four-week implantation in rats (Figure 6B) shows no significant differences in the micro-architecture of their surfaces. On the micrometer scale, the surfaces of both bead types look quite homogeneous, except for some wrinkles. By contrast, AFM images made from capsules labeled with perfluorocarbons and implanted for 15 months in rats show deposition of material (presumably collagen fibrils) on their surfaces (Figure 6C). The origin of the depositions is not clear at present. It is conceivable that the formation of fibril films was ultimately induced by the roughness of the gel surfaces or by crevices in the surface that may occur after exposure of the beads to mechanical shearing forces during implantation. In any case, the AFM results show that both the gelation process and the mechanical strength of the capsules should be improved.

\section{Swelling and Mechanical Strength}

Relatively smooth surfaces (without wrinkles) and improved permeability properties are likely when the cross-

Figure 6. Surface images of solid $\mathrm{Ba}^{2+}$ alginate capsules made of purified alginate (35). The images were acquired with an atomic force microscope in the non-contact mode. The beads were kept in liquid environment $(\mathrm{NaCl}$ solution) while scanning their surfaces. (A) Three-dimensional view of the surface of a capsule that was stored in an iso-osmolar $\mathrm{NaCl}$ solution for 29 days after preparation. The scan range is $6 \times 6$ $\mu \mathrm{m}^{2}$ and the z-scale is $0-297 \mathrm{~nm}$. On the right side of the picture, the topography of the surface is quite homogeneous, while the left side shows some imperfections. To accentuate these features the picture is left-shaded. (B) View of the surface of a capsule that had been implanted into the peritoneal cavity of a rat for four weeks. The scan range is $6 \times 6 \mu \mathrm{m}^{2}$; the height scale is $0-561 \mathrm{~nm}$. As in (A), the topography is quite homogeneous, but large corrugations can be seen across the surface. (C) Surface of an alginate-perfluorocarbon capsule (54), prepared from commercial purified alginate (left-shaded) retrieved from the peritoneal cavity of a Wistar rat after 15 months of implantation. The scan range is $8 \times 8 \mu \mathrm{m}^{2}$; the height scale is $0-691 \mathrm{~nm}$. In contrast to (A) and (B), the surface is rougher and shows fibrils and many corrugations. 
linking process of the alginate is not performed from outside to inside, but rather by internal gelation. In this process, capsules are formed from alginate solutions containing caged $\mathrm{Ca}^{2+}$ or caged $\mathrm{Ba}^{2+}(42)$ and a uniform crosslinkage is achieved by liberation of the reactive cations upon UV irradiation (35). Internal gelation can also be induced using carbonate salts of divalent cations and appropriate adjustment of the $\mathrm{pH}$ of the solutions (21).

Swelling of the capsules is another key factor that strongly affects the mechanical strength and the surface topography. Water activity in the capsules is greatly reduced by the polymers (61), particularly in the case of the alginatepoly-L-lysine capsules that contain a liquid core. Furthermore, most of the water is bound to the cross-linked polymers (22). This and the effects of the ion exchange and selectivity properties of hydrogels (53) give rise to a colloidosmotic pressure that causes the capsule to swell in saline solutions. Swelling can lead ultimately to disintegration of the matrix, even in the case of solid $\mathrm{Ba}^{2+}$ capsules (35). Workers in this field also know that implanted microcapsules frequently increase in size after retrieval from the transplantation site.

Research in this direction has led to the general belief $(7,49,52,69,75)$ that the degree of swelling depends on the M:G ratio, sequential structure, molec-
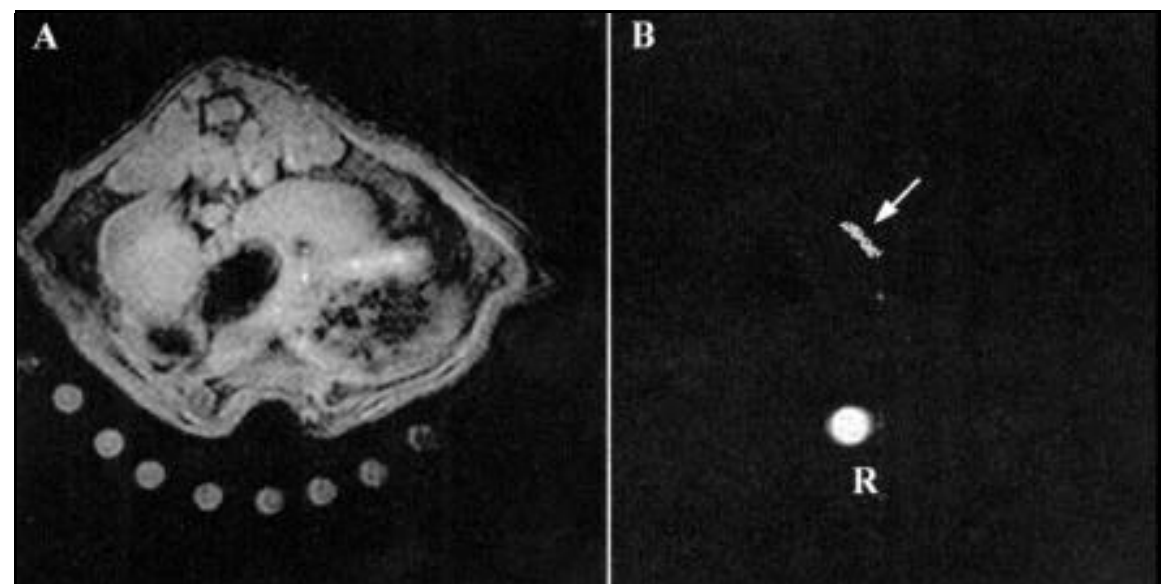

Figure 7. $1 \mathrm{H}-\mathrm{MR}$ (A) and 1 F-MR (B) images of a 3-mm-thick transaxial slice through the abdominal cavity of a female Wistar rat. The images were acquired about two years after implantation of perfluorocarbon-loaded $\mathrm{Ba}^{2+}$ alginate capsules $(350 \mu \mathrm{m}$ in diameter) under the kidney capsule. The in-plane resolution was $0.5 \times 0.5 \mathrm{~mm}$. The arrow marked the location of the implanted 19 -labeled beads. The letter $\mathrm{R}$ denotes a glass capillary ( $5 \mathrm{~mm}$ in diameter) filled with pure perfluorocarbon placed under the rat during the experiment as an external reference (54).

ular mass of the polymers and on the ratio of $\mathrm{Na}^{+}$to $\mathrm{Ca}^{2+}$ or $\mathrm{Ba}^{2+}$. Different strategies have been developed to stabilize the capsules and their surfaces against swelling (e.g., by using high-G alginate and chitosan as complexing agents) (26,44). A more general approach (independent of the composition and molecular mass of the alginate) is to incorporate serum proteins into the capsules during the gelation process and to remove immediately afterwards excessive divalent cations within the beads by a 30 -min incubation in $6 \mathrm{mM}$ sodium sulfate saline solutions (35) (Figure 4). This treatment leads to only a slight swelling immediately after preparation, and such modified capsules are stable for at least one year; the experiments are ongoing. Encapsulation of parathyroid tissue using this approach (including purified, highviscosity alginate) and subsequent transplantation into rats revealed superior properties compared to conventional capsules (unpublished data). Instead of proteins, medically approved (hydrophobic) perfluorocarbons can also be used because they show the same tendency as proteins to prevent swelling and thus considerably increase the long-term mechanical stability (Figure 4 and Figure 6C). Implantation experiments with perfluorocarbon-alginate capsules have been going on in our laboratory for more than two years.

\section{Long-Term Functional Stability of Encapsulated Cells and Monitoring Transplant Function}

Other matrix-related and host-related factors than material biocompatibility and surface compatibility are responsible for the functional loss of transplants.

The observation that necrosis occurs during transplantation in the core of the encapsulated islets suggests $(12,20,23)$ that graft failure is due to an insufficient supply of nutrients, particularly oxygen. If an unfavorable density of the encapsulated cells at a given transplantation site can be avoided, the stagnant fluid environment in the porous capsule matrix (diameter of the capsules usually between 500 and $800 \mu \mathrm{m}$ ) will be the key factor that restricts solute diffusion, as shown theoretically and experimentally in model systems $(5,29)$. Concentration gradients are established within the capsules, leading ultimately to cell necrosis. This depends not only on the size of the capsules but also on the cell density per bead. One approach to overcoming diffusion limitations is to decrease microcapsule diameter without loss of immunoprotection $(8,86$, 89). A second approach is to improve the diffusion properties of large capsules by high-viscosity alginate (together with internal gelation). In vitro and in vivo experiences in our laboratory have shown that high-viscosity alginate (a $0.1 \%$ solution corresponds to a viscosity of $10-20 \mathrm{cP}$ ) with narrow size distribution allows tuning of the permeation properties of the capsules exactly to the needs of optimum nutrient transfer and immunoprotection (Figure 4). In addition, increasing the molecular mass of the polymer, which is closely tied to viscosity, decreases cytotoxicity $(50,65)$ and improves mechanical stability. Thus, solid capsules made of appropriate concentrations of high-viscosity alginate (39) seem to solve the diffusion problems seen with largesized capsules prepared with low-viscosity alginates (a $0.1 \%$ solution corresponds to a viscosity of $1-5 \mathrm{cP}$ ).

Even with capsules exhibiting im proved permeation properties, nutrient supply (particularly oxygen) to the encapsulated cells may be limited by lack of vascularization of the capsules at the transplantation site. This is obviously 
an important factor when islet-containing capsules are transplanted into the unmodified peritoneal cavity where they float freely. At this location, the oxygen partial pressure is quite low and the nutrient supply depends on the slow diffusion from the blood to the peritoneal cavity $(20,78)$. The moment-tomoment regulation of blood glucose level by insulin secretion from this location (as required for the treatment of IDDM patients) is not possible. Selection of other implantation sites where a closer contact between the transplant and the blood can be established is therefore important. The muscle, liver and spleen are important candidates, but other transplantation sites for largesized microcapsules are conceivable because the oxygen supply of the encapsulated cells can be greatly enhanced by incorporation of perfluorocarbons into the capsules (Figure 4). These compounds, which prevent swelling of the alginate beads, are known for their high oxygen capacity (relative to the surrounding aqueous phase) and enhance oxygen transfer to the cells $(10,40,41)$.

Besides these beneficial features, perfluorocarbons have the further advantages that the ${ }^{19} \mathrm{~F}$-labeled beads can be monitored noninvasively by magnetic resonance imaging (MRI) and the oxygen partial pressure within the capsules can be calculated by changes in the fluorine spin-lattice relaxation time (54). In practice, ${ }^{19} \mathrm{~F}-\mathrm{MRI}$ is combined with ${ }^{1} \mathrm{H}$-MRI. Proton magnetic resonance images are made to obtain anatomical information about the transplantation site (Figure 7A). Because of the high water (proton) content of the alginate capsules (about 98\%), the implanted beads cannot be distinguished from the surrounding tissue. In contrast, ${ }^{19} \mathrm{~F}-$ MRI resolves the beads clearly even after long implantation periods (Figure
7B). Calculations of the oxygen partial pressure within the capsules have shown (54) - in agreement with expectations - that the peritoneal cavity and the kidney capsule are poor transplantation sites while muscle seems to be more appropriate.

Since oxygen transport has a profound effect on the viability and function of encapsulated cells, ${ }^{19} \mathrm{~F}$-perfluorocarbon-MRI can be used in the future as an early indicator for failure or migration of the graft, indicating the necessity of removal.

\section{Non-Autologous Donor Cells}

Evaluation of the problems encountered in developing long-term encapsulated cell therapy must also include discussion about the source of donor cells that deliver hormones, factors and other substances that the patient's own cells cannot produce. For the relatively 
low number of patients with clinical hypoparathyroidism, there should be no shortage of donor human parathyroid tissue. However, for treatment of an IDDM patient, about 1 million islets must be transplanted to cure diabetes. In view of the huge number of IDDM patients, the source of human organs is limited. Immunoisolation of porcine islets has the potential to fill the gap. Porcine islets are usually isolated from pancreatic tissue by the methods of Warnock and Rajotte (80) and Ricordi et al. (62). These methods are quite efficient, but the isolation of viable porcine islets in high yields is still subjected to a large variability (44). More recently, attention has turned to the isolation of islets from transgenic pigs (82). Genetic manipulation of donor pigs aims $(i)$ to completely eliminate natural human anti-pig antibody toxicity by producing transgenic pigs that inhibit complement-mediated lysis by antibodies (63); (ii) to inhibit glycosylation, which is a major target of natural human anti-pig antibodies (58); and (iii) to "knock out" pig MHC antigens (66) that differ between humans and pigs. However, even with the possibility of manufacturing genetically engineered cells, concerns remain about possible cross-species transmission of xenogeneic endogenous retrovirus $(57,59,73)$. Thus, propagation of human islets (or $\beta$-cells) in vitro or culture of transformed $\beta$-cells while maintaining normal function must be the ultimate goal $(15,37)$.

Transplantation of encapsulated cultured (genetically manipulated) cell lines that produce the required therapeutic factor has attracted the interest of many scientists because these cellular systems have many advantages com pared with cells isolated from animal tissue. A key advantage is that cell lines can be cultured under well-defined, reproducible and virus-free conditions, and the encapsulated cells can be characterized and stored a long time before clinical trials. It is agreed among those working in the field that regulatory approval of encapsulated, genetically manipulated cells will be less difficult and expensive compared to that of encapsulated animal cells. A problem with cell lines is, however, that growth in the encapsulated state must be prevented to avoid breakage of the support and subse- quent cell leakage. This can probably be achieved by careful control of the oxygen transfer to the encapsulated cells.

There is much literature on animal studies with encapsulated transformed cell lines for therapy of diabetes mellitus, Parkinson's disease, pain, uremia and neurodegenerative disorders $(1,4$, $11,15,21,32,44,64)$. Despite promising and far-reaching results, clinical success has been limited so far-as with islet xenotransplantation-because of non-biocompatible capsule material and capsule topography. However, the wide spectrum of cells that have been encapsulated and transplanted is indicative of the general utility of this approach for medical, research and biotechnological applications.

\section{CONCLUSIONS}

The concept of replacing nonfunctional tissue/cells of a patient by non-autologous cells/tissues to cure or prevent diseases is fascinating because the basic problems are corrected at the cellular level. In addition, the use of cell microencapsulation techniques in conjunction with genetic engineering techniques provides a powerful and efficient means for producing a wide range of therapeutic substances and thus corrections of disorders even at the genetic level.

Although the therapeutic efficacy of encapsulated cell therapy has been demonstrated in numerous animal studies and pilot clinical trials, several im provements need to be made before routine clinical applications can be considered. The advent of purified alginate was certainly an important step towards the realization of immunoisolated transplantation of non-autologous cells and tissues into patients. However, biocompatibility of the microcapsules in the broadest sense and, in turn, reproducible long-term function of the transplants continue to be problems; solutions to these and other problems are presented here, but they can only be solved by an interactive process because many features of the cell-microcapsule system are complex, interrelated and dependent on implantation site and delivery requirements. An integrated effort of a number of scientific disciplines is therefore needed to arrive at an advanced technology that will ultimately receive regulatory approval.

\section{ACKNOWLEDGMENTS}

We are very grateful to P. Amersbach, P. Geßner and G. HofmannPfannes for skillful technical assistance. We would like to thank S.G. Shirley for critical reading of the manuscript and B. Kuttler for performance of the implantation experiments in the $\mathrm{BB}$ rats. This work was supported by grant no. 0311716 of the BMBF and grant no. 13019 from the Deutsche Bundesstiftung Umwelt to U.Z., by grant nos. HA 2611/1-1 and GE 791$1 / 1$ from the Deutsche Forschungsgemeinschaft to C.H. and to the Lehrstuhl für Membranphysiologie, respectively.

\section{REFERENCES}

1.Aebischer, P., S.R. Winn, P.A. Tresco, C.B. Jaeger and L.A. Greene. 1991. Transplantation of polymer encapsulated neurotransmitter secreting cells: effect of the encapsulation technique. J. Biomech. Eng. 113:178-183.

2.Arfors, K.E. and K. Ley. 1993. Sulfated polysaccharides in inflammation. J. Lab. Clin. Med. 121:201-202.

3.Arnold, L.J., A. Dagan and N.O. Kaplan. 1983. Poly (L-lysine) as an antineoplastic agent and tumor-specific drug carrier, p. 89. 112. In E.P. Goldberg (Ed.), Targeted Drugs, Vol. 2. John Wiley \& Sons, New York.

4.Benson, J.P., K.K. Papas, I. Constantinidis and A. Sambanis. 1997. Towards the development of a bioartificial pancreas: effects of poly-L-lysine on alginate beads with BTC3 cells. Cell Transplant 6:395-402.

5.Beunink, J., H. Baumgärtl, W. Zimelka and H.-J. Rehm. 1989. Determination of oxygen gradients in single Ca-alginate beads by means of oxygen-microelectrodes. Experientia $45: 1041-1047$.

6.Brandenberger, H. and F. Widmer. 1998. A new multinozzle encapsulation/immobilisation system to produce uniform beads of alginate. J. Biotechnol. 63:73-80.

7.Brodelius, P. and E.J. Vandamme. 1987. Im mobilized cell systems, p. 405-464. In H.-J. Rehm and G. Reed (Eds.), Biotechnology, Vol. 7a. Verlag Chemie, Weinheim, Germany.

8. Calafiore, R., G. Basta, G. Luca, C. Boselli, A. Bufalari, A. Bufalari, M.P. Cassarani, G.M. Giustozzi and P. Brunetti. 1999. Transplantation of pancreatic islets contained in minimal volume microcapsules in diabetic high mammalians. Ann. NY Acad. Sci. 875:219-232

9.Casanova, D., E. Sarfati, A. de Francisco, J.A. Amado, M. Arias and C. Dubost. 1991. Secondary hyperparathyroidism: diagnosis of 
site of recurrence. World J. Surg. 15:546-550.

10.Chang, T.M.S. 1993. Blood Substitutes and Oxygen Carriers. Marcel Dekker, Inc., New York.

11.Chang, T.M.S. 1997. Artificial cells, p. 457463. In R. Dulbecco (Ed.), Encyclopedia of Human Biology, 2nd ed. Academic Press, San Diego.

12. Chicheportiche, D. and G. Reach. 1988. In vitro kinetics of insulin release by microencapsulated rat islets: effect of the size of the microcapsules. Diabetologia 31:54-57.

13.Clayton, H.A., R.F.L. James and N.J.M. London. 1993. Islet microencapsulation: a review. Acta Diabetologica 30:181-189.

14.Cochrum, K., S. Jemtrud and R. Dorian. 1995. Successful xenografts in mice with microencapsulated rat and dog islets. Transplant. Proc. 27:3297-3301.

15.Constantinidis, I., I. Rask, R.C. Long, Jr. and A. Sambanis. 1999. Effects of alginate composition on the metabolic, secretory, and growth characteristics of entrapped $\beta$ TC3 mouse insulinoma cells. Biomaterials 20:2019-2027.

16.Curtis, A. and C. Wilkinson. 1999. New depths in cell behaviour: reactions of cells to nanotopography. Biochem. Soc. Symp. 65:1526.

17.De Vos, P., B.J. De Haan and R. Van Schilfgaarde. 1997. Effect of the alginate composition on the biocompatibility of alginatepolylysine microcapsules. Biomaterials 18:273-278.

18.De Vos, P., B.J. De Haan, G.H.J. Wolters and R. Van Schilfgaarde. 1996. Factors influencing the adequacy of microencapsulation of rat pancreatic islets. Transplantation 62:888-893

19.De Vos, P., B.J. De Haan, G.H.J. Wolters, J.H. Strubbe and R. Van Schilfgaarde. 1997. Improved biocompatibility but limited graft survival after purification of alginate for microencapsulation of pancreatic islets. Diabetologia 40:262-270.

20.De Vos, P., J.F.M. Van Straaten, A.G. Nieuwenhuizen, M. de Groot, R.J. Ploeg, B.J. De Haan and R. Van Schilfgaarde. 1999. Why do microencapsulated islet grafts fail in the absence of fibrotic overgrowth? Diabetes 48:1381-1388.

21.Dulieu, C., D. Poncelet and R.J. Neufeld. 1999. Encapsulation and immobilization techniques, p. 3-17. In W.M. Kühtreiber, R.P. Lanza and W.L. Chick (Eds.), Cell Encapsulation Technology and Therapeutics. Birkhäuser, Boston.

22.Esch, M., V.L. Sukhorukov, M. Kürschner and U. Zimmermann. 1999. Dielectric properties of alginate beads and bound water relaxation studied by electrorotation. Biopolymers 50:227-237.

23.Fan, M.-Y., Z.-P. Lum, X.-W. Fu, L. Levesque, I.T. Tai and A.M. Sun. 1990. Reversal of diabetes in BB rats by transplantation of encapsulated pancreatic islets. Diabetes 39:519-522.

24.Fritschy, W.M., G.H.J. Wolters and R. Van Schilfgaarde. 1991. Effect of alginate-polylysine-alginate microencapsulation on in vitro insulin release from rat pancreatic islets. Diabetes 40:37-43.
25.Fuhr, G., E. Richter, H. Zimmermann, H. Hitzler, H. Niehus and R. Hagedorn. 1998. Cell traces - footprints of individual cells during locomotion and adhesion. Biol. Chem. 379:1161-1173

26.Gåserød, O., A. Sannes and G. SkjåkBræk. 1999. Microcapsules of alginate-chitosan. II. A study of capsule stability and permeability. Biomaterials 20:773-783.

27.Geisen, K., H. Deutschländer, S. Gorbach, C. Klenke and U. Zimmermann. 1990. Function of barium alginate-microencapsulated xenogenic islets in different diabetic mouse models, p. 142-148. In E. Shafrir (Ed.) II.8., Frontiers in Diabetes Research. Lessons from Animal Diabetes III. Smith-Gordon and Co. Ltd.

28.Gentile, F.T., E.J. Doherty, D.H. Rein, M.S. Shoichet and S.H. Winn. 1995. Polymer science for macroencapsulation of cells for central nervous system transplantation. Reactive Polymers 25:207-227.

29.Goosen, M.F.A. 1999. Mass transfer in im mobilized cell systems, p. 18-28. In W.M. Kühtreiber, R.P. Lanza and W.L. Chick (Eds.), Cell Encapsulation Technology and Therapeutics. Birkhäuser, Boston.

30.Gotfredsen, C.F., M.G. Stewart, G.M. O'Shea, J.R. Vose, T. Horn and A.J. Moody. 1990. The fate of transplanted encapsulated islets in spontaneously diabetic BB/Wor rats. Diabetes Res. 15:157-163.

31.Gröhn, P., G. Klöck and U. Zimmermann. 1997. Collagen-coated $\mathrm{Ba}^{2+}$-alginate microcarriers for the culture of anchorage-dependent mammalian cells. BioTechniques 22:970975 .

32.Hama, A.T. and J. Sagen. 1993. Reduced pain-related behavior by adrenal medullary transplants in rats with experimental painful peripheral neuropathy. Pain 52:223-231.

33.Hasse, C., G. Klöck, A. Schlosser, U. Zim mermann and M. Rothmund. 1997. Parathyroid allotransplantation without im munosuppression. The Lancet 350:12961297.

34.Hasse, C., A. Zielke, G. Klöck, A. Schlosser, P. Barth, U. Zimmermann, H. Sitter, W. Lorenz and M. Rothmund. 1998. Amitogenic alginates: key to the first clinical application of microencapsulation technology. World J. Surg. 22:659-665.

35.Hillgärtner, M., H. Zimmermann, S. Mimietz, A. Jork, F. Thürmer, H. Schneider, U. Nöth, C. Hasse et al. 1999. Immunoisolation of transplants by entrapment in 1 F-labelled alginate gels: production, biocompatibility, stability, and long-term monitoring of functional integrity. Mat.-wiss. u. Werkstofftech. 30:783-792.

36.Holcberg, I.B. and P. Margalith. 1981. Alcoholic fermentation by immobilized yeast at high sugar concentrations. Eur. J. Appl. Microbiol. Biotech. 13:133-140.

37.Howell, S.L. 1999. Future challenges in $\beta$-cell research. Adv. Mol. Cell. Biol. 29:337-346.

38.Hunkeler, D. 1997. Polymers for bioartificial organs. Trends Polym. Sci. 5:286-293.

39.Jork, A., F. Thürmer, H. Cramer, G. Zim mermann, P. Gessner, K. Hämel, G. Hofmann, B. Kuttler et al. 2000. Biocompatible alginate from freshly collected Laminaria pal- lida for implantation. Appl. Microbiol. Biotechnol. 53:224-229.

40.Ju, L.-K. and W.B. Armiger. 1992. Use of perfluorocarbon emulsions in cell culture. BioTechniques 12:258-263.

41.Junker, B.H., D.I.C. Wang and T.A. Hatton. 1990. Oxygen transfer enhancement in aqueous/perfluorocarbon fermentation systems: II theoretical analysis. Biotechnol. Bioengin. 35:586-597.

42.Kaplan, J.H. and G.C.R. Ellis-Davies. 1988. Photolabile chelators for the rapid photorelease of divalent cations. Proc. Natl. Acad. Sci. USA 85:6571-6575.

43. Klöck, G., H. Frank, R. Houben, T. Zekorn A. Horcher, U. Siebers, M. Wöhrle, K. Federlin and U. Zimmermann. 1994. Production of purified alginates suitable for use in immunoisolated transplantation. Appl. Microbiol. Biotechnol. 40:638-643.

44.Kühtreiber, W.M., R.P. Lanza and W.L. Chick. 1999. Cell Encapsulation Technology and Therapeutics. Birkhäuser, Boston.

45.Kulseng, B., G. Skjåk-Bræk, L. Ryan, A. Andersson, A. King, A. Faxvaag and T. Espevik. 1999. Transplantation of alginate microcapsules. Transplantation 67:978-984.

46.Lanza, R.P. 1999. Diffusion chambers, p. 40 52. In W.M. Kühtreiber, R.P. Lanza and W.L. Chick (Eds.), Cell Encapsulation Technology and Therapeutics. Birkhäuser, Boston.

47.Lanza, R.P., D.M. Ecker, W.M. Kühtreiber, J.P. Marsh, J. Ringeling and W.L. Chick. 1999. Transplantation of islets using microencapsulation: studies in diabetic rodents and dogs. J. Mol. Med. 77:206-210.

48.Lim, F. and A.M. Sun. 1980. Microencapsulated islets as bioartificial endocrine pancreas. Science 210:908-910.

49.Martinsen, A., G. Skjåk-Bræk and O. Smidsrød. 1989. Alginate as immobilization material: I. Correlation between chemical and physical properties of alginate gel beads. Biotechnol. Bioengin. 33:79-89.

50.Mattiasson, B. 1982. Immobilization methods, p. 3-26. In B. Mattiasson (Ed.), Immobilized Cells and Organelles, Vol. I. CRC Press, Boca Raton, FL.

51.Mazaheri, R., P. Atkison, C. Stiller, J. Dupré, J. Vose and G. O'Shea. 1991. Transplantation of encapsulated allogeneic islets into diabetic $\mathrm{BB} / \mathrm{W}$ rats. Effects of immunosuppression. Transplantation 51:750-754.

52.McHugh, D.J. 1987. Production, properties and uses of alginates, p. 58-115. In D.J. McHugh (Ed.), Production and Utilization of Products from Commercial Seaweeds. Food and Agriculture Organization of the United Nations, Rome, Italy.

53.Messiaen, J., P. Cambier and P. Van Cutsem. 1997. Polyamines and pectins. I. Ion exchange and selectivity. Plant Physiol. 113:387-395.

54.Nöth, U., P. Gröhn, A. Jork, U. Zimmermann, A. Haase and J. Lutz. 1999. 19F-MRI in vivo determination of the partial oxygen pressure in perfluorocarbon-loaded alginate capsules implanted into the peritoneal cavity and different tissues. Magn. Reson. Med. 42:1039-1047.

55.O'Shea, G.M. and A.M. Sun. 1986. Encapsulation of rat islets of Langerhans prolongs 
xenograft survival in diabetic mice. Diabetes 35:943-946.

56.Otterlei, M., A. Sundan, G. Skjåk-Bræk, L. Ryan, O. Smidsrød and T. Espevik. 1993. Similar mechanisms of action of defined polysaccharides and lipopolysaccharides: characterization of binding and tumor necrosis factor alpha induction. Infect. Immun. 61:19171925.

57.Paradis, K., G. Langford, Z. Long, W. Heneine, P. Sandstrom, W.M. Switzer, L.E. Chapman, C. Lockey, D. Onions et al. 1999. Search for cross-species transmission of porcine endogenous retrovirus in patients treated with living pig tissue. Science 285:1236-1241.

58.Parker, W., S. Saadi, S.S. Lin, Z.E. Holzknecht, M. Bustos and J.L. Platt. 1996. Transplantation of discordant xenografts: a challenge revisited. Immunol. Today 17:373378 .

59.Patience, C., Y. Takeuchi and R.A. Weiss. 1997. Infection of human cells by an endogenous retrovirus of pigs. Nat. Med. 3:282-286.

60.Peirone, M., C.J. D. Ross, G. Hortelano, J.L. Brash and P.L. Chang. 1998. Encapsulation of various recombinant mammalian cell types in different alginate microcapsules. J. Biomed. Mater. Res. 42:587-596.

61.Plumb, R.C. and W.B. Bridgman. 1972. Ascent of sap in trees. Science 176:1129-1131.

62.Ricordi, C., C. Socci, A.M. Davalli, C. Staudacher, P. Baro, A. Vertova, I. Sassi, F. Gavazzi et al. 1990. Isolation of the elusive pig islet. Surgery 107:688-694.

63. Rosengard, A.M., N. Cary, J. Horsley, C. Belcher, G. Langford, E. Cozzi, J. Wallwork and D.J.G. White. 1995. Endothelial expression of human decay accelerating factor of transgenic pig tissue: a potential approach for human complement inactivation in discordant xenografts. Transplant. Proc. 27:326327.

64.Ross, C.J.D., M. Ralph and P.L. Chang. 1999. Delivery of recombinant gene products to the central nervous system with nonautologous cells in alginate microcapsules. Hum. Gene Ther. 10:49-59.

65.Schneider, S., P.J. Feilen, A. Jork, F. Thürmer, T.A. Sagban, V. Slotty, S. Berger, R. Pommersheim et al. Biocompatibility and functionality of alginates for islet grafting: im pact of alginate and sterilization procedures. Appl. Microbiol. Biotechnol., submitted.

66.Seebach, J.D., K. Yamada, I.S. McMorrow, D.H. Sachs and H. DerSimonian. 1996. Xenogeneic human anti-pig cytotoxicity mediated by activated natural killer cells. Xenotransplantation 3:188-197.

67.Skalak, R. and C.F. Fox. 1988. Tissue Engineering. Alan R. Liss Inc., New York.

68.Skjåk-Bræk, G., E. Murano and S. Paoletti. 1989. Alginate as immobilization material. II: determination of polyphenol contaminants by fluorescence spectroscopy, and evaluation of methods for their removal. Biotechnol. Bioengin. 33:90-94.

69.Smidsrød, O. and G. Skjåk-Bræk. 1990. Alginate as immobilization matrix for cells. Trends Biotechnol. 8:71-78.

70.Soon-Shiong, P., E. Feldman, R. Nelson, J. Komtebedde, O. Smidsrød, G. Skjåk-Bræk,
T. Espevik, R. Heintz and M. Lee. 1992 Successful reversal of spontaneous diabetes in dogs by intraperitoneal microencapsulated islets. Transplantation 54:769-774.

71.Soon-Shiong, P., R.E. Heintz, N. Mrideth, Q.X. Yao, Z. Yao, T. Zheng, M. Murphy, M.K. Moloney et al. 1994. Insulin independence in a type 1 diabetic patient after encapsulated islet transplantation. The Lancet 343:950-951.

72.Sun, Y., X. Ma, D. Zhou, I. Vacek and A.M. Sun. 1996. Normalization of diabetes in spontaneously diabetic cynomologus monkeys by xenografts of microencapsulated porcine islets without immunosuppression. J. Clin. Invest. 98:1417-1422.

73. Tacke, S.J., R. Kurth and J. Denner. 2000 Porcine endogenous retroviruses inhibit human immune cell function: risk for xenotrans plantation? Virology 268:87-93

74. Tajima, S., H. Inoue, A. Kawada, A. Ishibashi, H. Takahara and N. Hiura. 1999. Alginate oligosaccharides modulate cell morphology, cell proliferation and collagen expression in human skin fibroblasts in vitro. Arch. Dermatol. Res. 291:432-436

75. Tanaka, H. and S. Irie. 1988. Preparation of stable alginate gel beads in electrolyte solutions using $\mathrm{Ba}^{2}+$ and $\mathrm{Sr}^{2}+$ Biotechnol. Techniques 2:115-120.

76. Van Schilfgaarde, R. and P. De Vos. 1999. Factors influencing the properties and performance of microcapsules for immunoprotec tion of pancreatic islets. J. Mol. Med. 77:199205 .

77. Vansteenkiste, S.O., M.C. Davies, C.J. Roberts, S.J.B. Tendler and P.M. Williams. 1998. Scanning probe miscroscopy of biomedical interfaces. Prog. Surf. Sci. 57:95-136.

78. Velho, G., P. Froguel and G. Reach. 1989. Determination of peritoneal glucose kinetics in rats: implications for the peritoneal implantation of closed-loop insulin delivery systems. Diabetologia 32:331-336.

79.Wang, T.G. 1999. Polymer membranes for cell encapsulation, p. 29-39. In W.M. Kühtreiber, R.P. Lanza and W.L. Chick (Eds.), Cell Encapsulation Technology and Therapeutics. Birkhäuser, Boston.

80.Warnock, G.L. and R.V. Rajotte. 1988. Critical mass of purified islets that induce normoglycemia after implantation into dogs. Diabetes 37:467-470.

81. Weber, C., M. Costanzo, S. Krekun and V. D'Agati. 1993. Causes of destruction of microencapsulated islet grafts: characteristics of a "double-wall" poly-L-lysine-alginate microcapsule. Diabetes Nutr. Metab. 1:167-171.

82.Weber, C.J., J.A. Kapp, M.K. Hagler, S. Safley, J.T. Chryssochoos and E.L. Chaikof. 1999. Long-term survival of poly-L-lysine-alginate microencapsulated islet xenografts in spontaneously diabetic NOD mice, p. 117137. In W.M. Kühtreiber, R.P. Lanza and W.L. Chick (Eds.), Cell Encapsulation Technology and Therapeutics. Birkhäuser, Boston.

83.Wijsman, J., P. Atkison, R. Mazaheri, B. Garcia, T. Paul, J. Vose, G. O'Shea and C. Stiller. 1992. Histological and immunopathological analysis of recovered encapsulated allogeneic islets from transplanted diabetic $\mathrm{BB} / \mathrm{W}$ rats. Transplantation 54:588-592.
84.Xu, K., D.M. Hercules, I. Lacik and T.G. Wang. 1998. Atomic force microscopy used for the surface characterization of microcapsule immunoisolation devices. J. Biomed. Mater. Res. 41:461-467.

85.Zekorn, T.D.C. and R.G. Bretzel. 1999. Im munoprotection of islets of Langerhans by microencapsulation in barium alginate beads, $\mathrm{p}$. 90-96. In W.M. Kühtreiber, R.P. Lanza and W.L. Chick (Eds.), Cell Encapsulation Technology and Therapeutics. Birkhäuser, Boston.

86.Zekorn, T., U. Siebers, A. Horcher, R. Schnettler, U. Zimmermann, R.G. Bretzel and K. Federlin. 1992. Alginate coating of islets of Langerhans: in vitro studies on a new method for microencapsulation for immunoisolated transplantation. Acta Diabetologica 29:41-45.

87.Zhou, D., Y.L. Sun, I. Vacek, P. Ma and A.M.Sun. 1994. Normalization of diabetes in cynomolgus monkeys by xenotransplantation of microencapsulated porcine islets. Transplant. Proc. 26:1091

88.Zimmermann, H., R. Hagedorn, E. Richter and G. Fuhr. 1999. Topography of cell traces studied by atomic force microscopy. Eur. Biophys. J. 28:516-525.

89.Zimmermann, U., C. Hasse, M. Rothmund and W. Kühtreiber. 1999. Biocompatible encapsulation materials: fundamentals and application, p. 40-52. In W.M. Kühtreiber, R.P. Lanza and W.L. Chick (Eds.), Cell Encapsulation Technology and Therapeutics. Birkhäuser, Boston.

90.Zimmermann, U., G. Klöck, K. Federlin, K. Hannig, M. Kowalski, R.G. Bretzel, A. Horcher, H. Entenmann et al. 1992. Production of mitogen-contamination free alginates with variable ratios of mannuronic acid to guluronic acid by free flow electrophoresis. Electrophoresis 13:269-274.

\section{Address correspondence to:}

Prof. U. Zimmermann

Lehrstuhl für Biotechnologie

Biozentrum, Am Hubland, D-97074

Würzburg, Germany

e-mail: zimmerma@biozentrum.uni-

wuerzburg.de 